\title{
Steuerrechtliche Einzelschriften.
}

Herausgegeben von

Dr. Alfred Friedmann, und Dr. Richard Wrzeszinski, Rechtsanwalt am Kammergericht in Berlin.

\section{Schrift 4}

\section{Das neule Stenerpecht

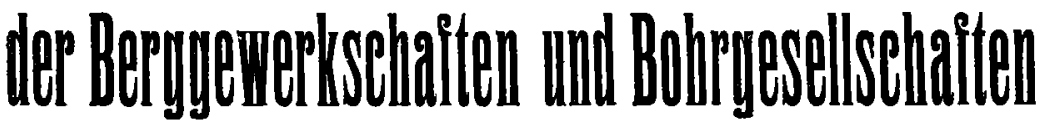

Von

Dr. Rudolf Isay,

Rechtsanwalt am Kammergericht.

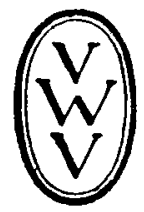

Berlin und Leipzig 1920.

Vereinigung wissenschaftlicher Verleger

Walter de Gruyter \& Co.

vormals G. J. Göschen'sche Verlagshandlung - J. Guttentag, Verlagsbuchhandlung -

Georg Reimer - Karl J. Trübner - Veit \& Comp. 


\section{Abkürzungs - Verzeichnis.}

ABG.: Allgemeines Berggesetz für die preußischen Staaten.

EinkStG.: Einkommensteuergesetz vom 29. März 1920 (Reichsgesetz blatt S. 359).

HGB.: Handelsgesetzbuch.

Isay: Dr. H. u. R. Isay, Kommentar zum Allgemeinen Berg. gesetz Band 1 und 2.

KESTG.: Kapitalertragsteuergesetz v. 29. März 1920.

KörpStG.: Körperschaftssteuergesetz vom 30. März 1920 (RGBl. S. 393).

KrStG.: Kriegssteuergesetz vom 21. Juni 1916.

OVG.: $\quad$ Oberverwaltungsgericht.

OVG. i. St. : Entscheidungen des Oberverwaltungsgerichts in Staatssteuersachen.

PrEinkStG.: Preußisches Einkommensteuergesetz vom 19. Juni 1906

RAO.: Reichsabgabenordnung vom 13. Dezember 1919 (Reichsgesetzblatt S. 1993).

RFH.: Reichsfinanzhof (Sammlung seiner Entscheidungen und Gutachten).

RNO.: Reichsgesetz über das Reichsnotopfer vom 31. Dezember 1919 (RGBl. S. 2189).

Zeitschr. f. Bergr.: Zeitschr. f. Bergrecht, gegründet von Brassert. 